\title{
Psychomotorika a sebeobrana jako účinná pohybová intervence ovlivňující výkonovou motivaci jedinců se sluchovým postižením
}

\section{Psychomotor and physical self-defense as an effective intervention influencing the achievement motivation of individuals with hearing disabilities}

\author{
Marin Dlouhý $^{1}$ Jana Dlouhá $^{2}$, Milan Slezáček $^{3}$, Věra Kuhnová ${ }^{1}$ \\ ${ }^{1}$ Pedagogická fakulta, Univerzita Karlova, Praha \\ ${ }^{2}$ Pedagogická fakulta, Univerzita Hradec Králové \\ ${ }^{3}$ Centrum sportovních aktivit, Vysoké učení technické, Brno
}

\begin{abstract}
Abstrakt
Článek se zabývá problematikou rozvoje výkonové motivace u mládeže se sluchovým postižením v období adolescence prostřednictvím intervenčního pohybového programu. Cílem výzkumu bylo ovlivnit specifickým sportovně pohybovým programem výkonovou motivaci u mládeže se sluchovým postižením.

$V$ rámci metodiky práce byl zvolen základni empirický postup prostřednictvím pedagogického experimentu. Hlavním experimentálním činitelem byl intervenční pohybový program, který se skládal ze základi̊ sebeobrany a psychomotoriky. V rámci metodiky zjišstování úrovně aspirace, byl použit Test aspirace (Bakalár̆, 1987). Pro vytvoření intervenčního pohybového programu byla použita metoda analýzy a syntézy zkoumaných dat a vyhodnoceni ziskaných výsledků bylo provedeno základními statistickými metodami. Stanovená hypotéza, že vlivem intervenčního programu se zvýši úroveň výkonové motivace u experimentální skupiny mládeže se sluchovým postižením, byla potvrzena. Výzkum potvrdil předpoklad, že základy sebeobrany a psychomotoriky maji signifikantní vliv na rozvoj výkonové motivace u vybrané skupiny mládeže se sluchovým postižením. Tento článek je dílči součástí úspěšně obhájené disertační práce na FSpS MUv Brně.
\end{abstract}

\begin{abstract}
The article deals with the development of achievement motivation of young people with hearing impairment during adolescence through a special intervention program. The aim was to influence the sport specific movement program the achievement motivation of the youth with hearing disabilities. The methodology of the work he was elected a basic empirical approach using a simple experiment. The main factor was the experimental intervention movement program that consisted of the foundations of basic self-defense and psychomotor. The main research method was the aspiration test (Bakalár, 1987). Hypotheses that the effects of the intervention program will increase the level of achievement motivation in the experimental group of young people with hearing disabilities was confirmed. Research confirmed the assumption that the fundamentals of self defense and psychomotor have a significant influence on the development of achievement motivation of the selected group of young people with hearing impairments. This article is part of the sub successfully defended his dissertation on FSpS MU in Brno.
\end{abstract}

Kličová slova: výkonová motivace, mládež, sluchové postižení, intervenční pohybový program

Key words: the adolescent young people, the hearing disability, special interventional program, achievement motivation

\section{ÚVOD}

Sluch je kromě zraku jedním z hlavních smyslů člověka a je současně jedním z těch, které pracují nepřetržitě, aniž bychom si to uvědomovali. Poškození či dokonce ztráta kteréhokoliv smyslu je pro člověka zcela mimořádným handicapem. $\mathrm{V}$ důsledku takové ztráty je pro člověka mnohem obtížnější zařadit se do tzv. 
normálního běžného života a aktivní účasti v mnohých činnostech včetně následných prožitků z nich, které jsou pro člověka tak potřebné. Ztráta sluchu patří mezi nejzávažnější problémy, které mohou způsobovat poruchy v mnoha dimenzích osobnosti. Porucha sluchu nebo dokonce jeho úplná ztráta tudíž zásadně ovlivňuje člověka v celém životě.

Je evidentní, že k prvkům zdraví přispívá pohybová aktivita. Všechny její formy pomáhají člověku při naplňování spokojené životní cesty. Proto jsou tělesná výchova, sport a sportovně pohybové aktivity důležitou součástí života každého z nás a jejich prostřednictvím můžeme odstraňovat životní nejistoty a hledat vlastní cesty ve smyslu naplňování života a zdraví. Sport a pohybová aktivita, jakožto významný fenomén našeho bytí je taktéž neopominutelnou součástí integrace jedinců nejen se smyslovým postižením. Sportovní resp. pohybová aktivita ovlivňuje osobnost a jeho dimenze jako např. pozornost či výkonová motivace atd. a často bývá v naší společnosti dosti podceňovaným mj. terapeutickým činitelem v rámci podpory zdravého životního stylu - nejen u jedinců se sluchovým handicapem.

Výkonová motivace je chápána jako očekávání určitých afektivních změn ve vztahu k dosažení nebo nedosažení cíle, konkrétně jde o motivační vliv naděje na úspěch a strach z neúspěchu, závislý na zkušenostech jdoucích až k výchově v rodině, na kauzálních atribucích a dalších činitelích (Blahutková, 2005). Motivace k výkonu bývá označována jako potřeba subjektu dosahovat úspěchy různých druhů činností, hlavně při soutěžení s jinými lidmi. Základem výkonové motivace jsou afektivně podbarvené asociace, které spojují vnitřní prožitky člověka a jeho chování (Abramenková, 1987).

Jednou z nejdůležitějších složek, která zásadně ovlivňuje úroveň výkonové motivace je aspirace.

Aspirační úroveň patří k problémům, kterým se již dříve věnovala velká pozornost v souvislosti se zájmem o otázky motivace. Můžeme ji definovat jako úroveň cílů, které si člověk vytyčuje a jejichž dosažení očekává. Dosažení těchto cílů pak prožívá jako úspěch, nedosažení jako neúspěch (Hrabal, 1989).

Aspirace má vždy určitý obsah a určitá kvalitativní hlediska. Aspirační úroveň je důležitou charakteristikou činnosti jedince. Jedná se o životní cíle a s nimi spojená míra úsilí potřebného k jejich dosažení (Nakonečný, 1995).

Je všeobecně známo, že pohybová resp. sportovní aktivita u člověka ovlivňuje mj. kromě pozornosti také oblast výkonové motivace. Jednou ze specifických pohybových aktivit, které jsou v tomto př́ípadě velmi vhodné je např. psychomotorika (Blahutková, 2005 aj.) a také sebeobrana resp. bojová umění (Nakayama, 1966; Oyama, 1966, Dlouhý, 2002; Kurfürst, 1994, aj.) a tyto pohybové činnosti jsou také obecně vhodné i pro jedince s různým druhem smyslového postižení - sluchový handicap nevyjímaje.

\section{METODIKA}

\section{Cíl práce}

Cílem výzkumu bylo prokázat vliv intervenčního pohybového programu sestaveného z psychomotoriky a sebeobrany na výkonovou motivaci u mládeže se sluchovým postižením.

\section{Hypotéza - Předpokládáme, že vlivem pedagogického experimentu se signifikantně zvýší výkonová motivace u experimentální skupiny mládeže se sluchovým postižením.}

V rámci metodiky práce byl zvolen základní empirický postup prostřednictvím pedagogického experimen.

V rámci měření pozornosti byl zvolen standardizovaný Test úrovně aspirace (Bakalář, 1987). Měření probíhalo formou pre-test a post-test. Nejdůležitější složkou výkonové motivace je úroveň aspirace, která jakožto zásadní subsystém je také hlavním měřítkem velikosti výkonové motivace (tudíž předmětem měření výkonové motivace) a proto, pokud je třeba zjistit úroveň výkonové motivace, používá se k tomu test úrovně aspirace v našem př́ípadě výše uvedený základní standardizovaný Test úrovně aspirace (Bakalář 1987). Vyhodnocení získaných dat bylo provedeno metodou statistické analýzy základních statistických veličin.

Hlavním experimentálním činitelem byl specifický intervenční pohybový program, který se skládal za základů sebeobrany a psychomotoriky (tzn. úpoly, úpolové hry, průpravné, základní a jiné úpoly; základy prvků sebeobrany z juda, karate, kung fu a jiu-jitsu; psychomotorika, psychomotorické hry, pro jednotlivce, skupinky, družstva, celou skupinu, s náčiním i bez, včetně žonglování apod.), vytvořený s ohledem na žáky se sluchovým postižením a jejich speciální vzdělávací potřeby. Intervenční program byl zaměřen na zvyšování úrovně výkonové motivace a pozornosti.

Výzkum probíhal na SŠ pro sluchově postižené v Hradci Králové formou 1 vyučovací hodiny 2x týdně 
po dobu $1 / 2$ roku, hodin se zúčastnili učitel TV, překladatelé (kteří nezasahovali do průběhu hodin) a osoba provádějící výzkum. Celkem bylo aplikováno 40 hodin speciálního pohybového programu.

Test úrovně aspirace se provádí formou tužka - papír do předem stanoveného formuláře. Před probanda se položí záznamový arch a vysvětlí se mu, že jeho úkolem je udělat během 10 vteřin co nejvíce křížků do čtverečků (v obrazci $3 \times 9$ tj. 3 řady a 9 sloupců). Po dotazu na jeho odhad se tento zapíše do čtverce vedle tabulky s označením $\mathrm{O} 1$ (odhad 1). Poté je proveden test, který trvá 10 vteřin. Čas i další instrukce je nutné přesně dodržet. Skutečný počet křížků při prvním pokusu se zapíše do čtverečku V1 (výkon 1) vedle tabulky (pod čtverečkem O1). Při dalších pokusech jsou analogické instrukce. Celkem jsou 4 pokusy. Při třetím pokusu však bez vědomí probanda se zkrátí časový limit o 2 vteřiny tj. na 8 vteřin. Poslední čtvrtý pokus je již opět v původním časovém limitu 10 vteřin. Výsledky se porovnají s normou a vyhodnotí.

\section{Vzorec pro výpočet testu úrovně aspirace:}

\section{$\mathrm{A}=\mathrm{O} 2-\mathrm{V} 1+\mathrm{O} 3-\mathrm{V} 2+\mathrm{O} 4-\mathrm{V} 3$}

3

A - aspirace

$\mathrm{O} 2$ - 4 - odhad

V1-3 - výkon

\section{Výsledek porovnávaný s normou:}

5,00 - více - velmi vysoká

3,00 - 4,99 - vysoká

1,00 - 2, - normální

-1,5 - 1 - nízká

-1,5 - níže - velmi nízká

\section{Charakteristika výzkumného souboru}

Výběr výzkumného souboru byl záměrný (dle níže uvedených kritérií). Experimentální skupinu tvořilo celkem 14 probandů ( 8 dívek a 6 chlapců) Střední školy pro sluchově postižené resp. Střední pedagogické školy pro sluchově postižené v Hradci Králové ve věkové kategorii adolescence v tomto př́padě v rozmezí $17-21$ let (tab. 2). Charakter sluchového postižení: (Horáková, In Pipeková, 2006) středně těžká - těžká vada sluchu. Kontrolní skupinu tvořilo rovněž celkem 14 probandů ( 8 dívek a 6 chlapců) výše uvedené školy ve stejné věkové kategorii adolescence v rozmezí 17 - 21 let (tab. 1) stejně jako u experimentální skupiny. Charakter sluchového postižení byl rovněž stejný jako u této skupiny. Vzhledem k tomu, že jde o největší školu tohoto typu v ČR, jedná se takřka o vyčerpávající počet.

\section{VÝSLEDKY}

Pro verifikaci hypotézy byl použit test úrovně aspirace (Bakalář, 1987). Výsledky testu úrovně aspirace u kontrolní a experimentální skupiny jsou vyjádřeny v bodech (tab. 1 - 2). Ze zjištěných hodnot vyplývá, že u mužů byly výsledky v testu úrovně aspirace na konci experimentu vyšší o hodnotu 2,73 bodu než u kontrolní skupiny. U žen byly výsledky v testu úrovně aspirace na konci experimentu nižší o hodnotu - 0,12 bodu než u kontrolní skupiny. Celkově byly výsledky vlivem intervenčního pohybového programu v testu úrovně aspirace měřené standardizovaným Testem úrovně aspirace (Bakalář, 1987) u experimentální skupiny na konci experimentu vyšší o hodnotu 1,1 bodu než u kontrolní skupiny. 
Tab. 1: Výsledky měrení testu úrovně aspirace u kontrolní skupiny adolescentů

\begin{tabular}{|l||l|l|l|}
\hline $\begin{array}{l}\text { Testovaná osoba - } \\
\text { pohlaví (M, F) }\end{array}$ & $\begin{array}{l}\text { Vstupní šetření } \\
\text { (pre-test) }\end{array}$ & $\begin{array}{l}\text { Výstupní } \\
\text { (post-test) }\end{array}$ & Rozdíl \\
\hline \hline TO 1 M & $-2,33$ & $-4,66$ & $-2,33$ \\
\hline \hline TO 2 M & $+2,33$ & $-1,33$ & $-3,6$ \\
\hline \hline TO 3 M & $+3,66$ & $+4,66$ & +1 \\
\hline \hline TO 4 M & $+0,66$ & $+0,33$ & $-0,33$ \\
\hline \hline TO 5 M & $+5,33$ & +5 & $-0,33$ \\
\hline \hline TO 6 M & -2 & -2 & 0 \\
\hline TO 7 F & $-0,66$ & -1 & $-0,34$ \\
\hline \hline TO 8 F & $+0,66$ & $-1,33$ & $-1,99$ \\
\hline \hline TO 9 F & 0 & $+0,33$ & $+0,33$ \\
\hline \hline TO 10 F & +1 & $+2,66$ & $+1,66$ \\
\hline TO 11 F & -7 & $-5,66$ & $+1,34$ \\
\hline \hline TO 12 F & $-0,33$ & 0 & $+0,33$ \\
\hline \hline TO 13 F & $-6,66$ & -7 & $-0,34$ \\
\hline \hline TO 14 F & $+2,66$ & $+4,66$ & +2 \\
\hline \hline
\end{tabular}

Tab. 2: Výsledky měreni testu úrovně aspirace u experimentální skupiny adolescence

\begin{tabular}{|c|c|c|c|}
\hline $\begin{array}{l}\text { Testovaná osoba } \quad- \\
\text { pohlaví }(\mathrm{M}, \mathrm{F})\end{array}$ & $\begin{array}{l}\text { Vstupní } \\
\text { (pre-test) }\end{array}$ & $\begin{array}{l}\text { Výstupní šetření } \\
\text { (post-test) }\end{array}$ & Rozdíl \\
\hline TO $1 \mathrm{M}$ & -5 & -3 & +2 \\
\hline TO $2 \mathrm{M}$ & 0 & 0 & 0 \\
\hline TO $3 \mathrm{M}$ & $-1,45$ & $+1,15$ & $+2,6$ \\
\hline $\mathrm{TO} 4 \mathrm{M}$ & -1 & -1 & 0 \\
\hline TO $5 \mathrm{M}$ & -2 & $+1,66$ & $+3,66$ \\
\hline TO $6 \mathrm{M}$ & $-1,45$ & $+1,15$ & $+2,6$ \\
\hline TO $7 \mathrm{~F}$ & +3 & +4 & +1 \\
\hline TO $8 \mathrm{~F}$ & $-1,66$ & 0 & $+1,66$ \\
\hline TO $9 \mathrm{~F}$ & $+0,33$ & $-5,3$ & $-5,66$ \\
\hline TO $10 \mathrm{~F}$ & $+1,33$ & $-4,3$ & $-5,66$ \\
\hline TO $11 \mathrm{~F}$ & $+0,66$ & $+3,06$ & $+2,4$ \\
\hline TO $12 \mathrm{~F}$ & $-2,66$ & $+3,33$ & $+5,99$ \\
\hline TO $13 \mathrm{~F}$ & $-6,3$ & $-7,1$ & $-0,8$ \\
\hline TO $14 \mathrm{~F}$ & -2 & $+1,1$ & $+3,1$ \\
\hline
\end{tabular}


Výsledky měření z hlediska rozložení četnosti v daných pásmech normy u kontrolní a experimentální skupiny $\mathrm{v}$ rámci testu úrovně aspirace a jejich porovnání vyjadřuje obr. 1 - 2 .

Obr. 1: Výsledky měreni úrovně aspirace u kontrolní skupiny

\section{Probandi}

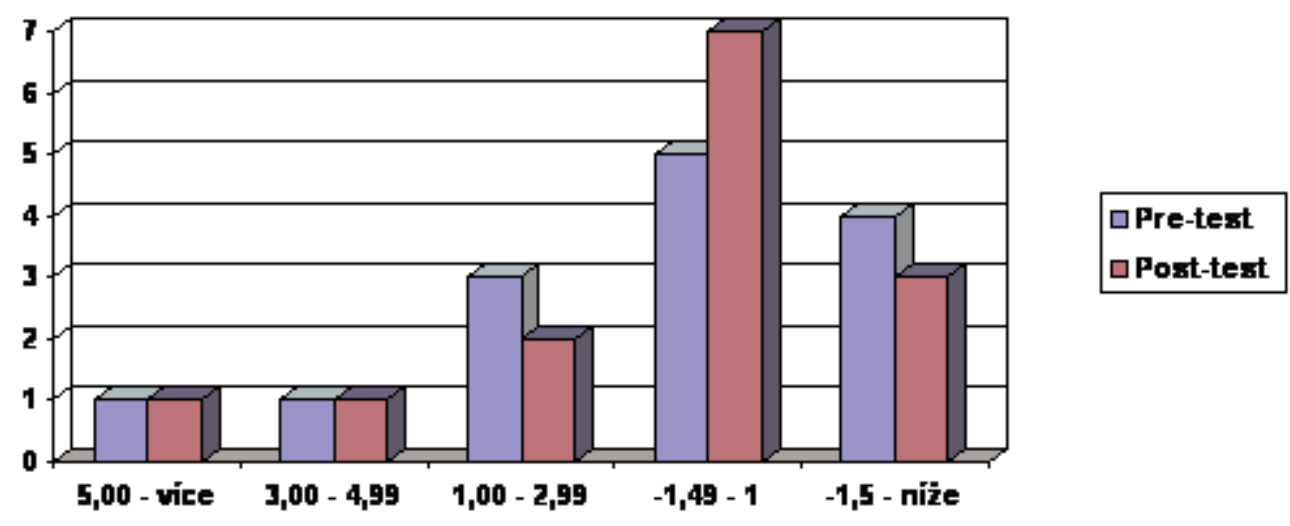

Pásmo normy

Obr. 2: Výsledky měření úrovně aspirace u experimentální skupiny

\section{Probandi}

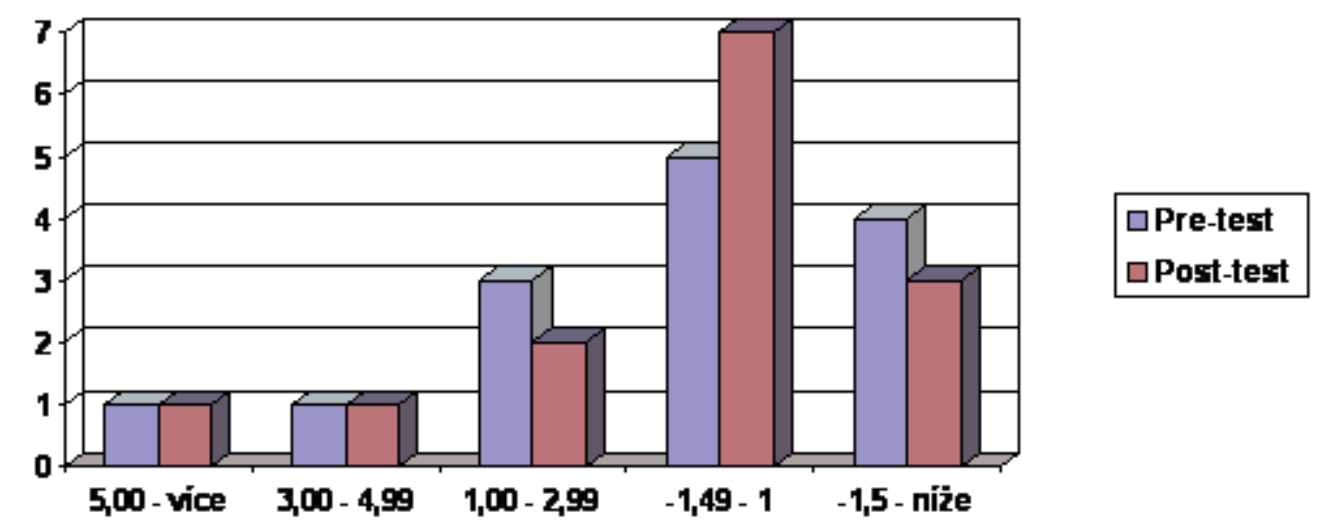

Pásmo normy 


\section{Základní statistické charakteristiky}

U statistického vyhodnocování výkonové motivace jsme zjistili následující fakta (tab. 3 - 5).

Tab. 3: Kontrolní skupina - ASPIRACE

\begin{tabular}{|l|l|l|l|l|l|}
\hline Veličina & N & Průměr & Minimum & Maximum & Sm.odch. \\
\hline Aspirace: Pre-test všichni & 14 & $-0,19143$ & $-7,00000$ & 5,3300 & 3,49721 \\
\hline Aspirace: Post-test všichni & 14 & $-0,38143$ & $-7,00000$ & 5,0000 & 3,77213 \\
\hline průměrné zhoršení & & 0,19 & & & \\
\hline & & & & & \\
\hline pohlaví=M & & & & & \\
\hline Aspirace: Pre-test & 6 & 1,27500 & $-2,33000$ & 5,33000 & 3,07715 \\
\hline Aspirace: Post-test & 6 & 0,33333 & $-4,66000$ & 5,00000 & 3,83777 \\
\hline průměrné zhoršení & & 0,94167 & & & \\
\hline & & & & & \\
\hline pohlaví=Ž & 8 & $-0,91750$ & $-7,00000$ & 4,6600 & 3,89083 \\
\hline Aspirace: Pre-test & & $-0,37375$ & & & \\
\hline Aspirace: Post-test & & & & & \\
\hline průměrné zlepšení & & & & & \\
\hline
\end{tabular}

Tab. 4: Experimentální skupina - ASPIRACE

\begin{tabular}{|c|c|c|c|c|c|}
\hline Veličina & $\mathrm{N}$ & Průměr & Minimum & Maximum & Sm.odch. \\
\hline Aspirace: Pre-test všichni & 14 & $-1,30000$ & $-6,30000$ & 3,0000 & 2,40799 \\
\hline Aspirace: Post-test všichni & 14 & $-0,37500$ & $-7,10000$ & 4,0000 & 3,37507 \\
\hline průměrné zlepšení & & $-0,925$ & & & \\
\hline \multicolumn{6}{|l|}{ pohlaví=M } \\
\hline Aspirace: Pre-test & 6 & $-1,81667$ & $-5,00000$ & 0,00000 & 1,69725 \\
\hline Aspirace: Post-test & 6 & $-0,00667$ & $-3,00000$ & 1,66000 & 1,75501 \\
\hline průměrné zlepšení & & $-1,81$ & & & \\
\hline \multicolumn{6}{|l|}{ pohlaví=Ž } \\
\hline Aspirace: Pre-test & 8 & $-0,91250$ & $-6,30000$ & 3,0000 & 2,88279 \\
\hline Aspirace: Post-test & 8 & $-0,65125$ & $-7,10000$ & 4,0000 & 4,33028 \\
\hline průměrné zlepšení & & $-0,26125$ & & & \\
\hline
\end{tabular}

Tab. 5: ASPIRACE - pre-test \& post-test - shrnutí

\begin{tabular}{|l||l|l||l|}
\hline Aspirace & všichni & muži & ženy \\
\hline \hline \multirow{2}{*}{ kontrolní } & 0,19 & & \\
\hline \hline & & 0,94 & $-0,37375$ \\
\hline & & & \\
\hline
\end{tabular}




\section{DISKUSE}

Ze zjištěných výsledků výzkumu vyplývá, že výše uvedený pedagogický experiment resp. intervenční pohybový program měl zřetelný vliv na výkonovou motivaci, která se vlivem intervenčního programu změnila.

Pedagogického experimentu se zúčastnilo 28 adolescentů (14 probandů v kontrolní a 14 experimentální skupině). Což je mnohem větší počet, než standardní počet studentů v hodinách tělesné výchovy, kde je tento počet studentů mnohem nižší (viz vyhláška 62/2007 Sb.). Tím byla následně celá realizace pedagogického experimentu mnohem náročnější a je možné, že to mohlo ovlivnit výsledky tohoto experimentu, které díky tomu mohly být nižší, než se původně očekávalo a speciální intervenční program tak mohl mít paradoxně v podstatě menší efekt, který se promítl do zjištěných výsledků. V pedagogické praxi a to nejen v základním školství logicky platí, že čím více účastníků v hodině, tím je vyučování náročnější a méně efektivní. Čím větší počet studentů v hodině, tím více je rozptylována jejich pozornost a tím obtížněji se koncentrují. Aby se tento problém aspoň částečně eliminoval, na každé hodině byli př́itomni vždy 3 stálí př̌sně instruovaní pracovníci, kteří se podíleli na dané výuce.

Získávání většího počtu jedinců je však velmi omezené a obtížné kvůli specifičnosti vybrané skupiny, tzn. mládeže se sluchovým postižením a z toho vyplývající náročnosti př́pravy i realizace výzkumu s event. větším počtem vybraného souboru. V České republice je velmi málo škol pro sluchově postižené. Ještě méně je těch, kde by bylo možné získat větší výzkumný soubor, který by vyhovoval výzkumu kvantitativního zaměření.

Provádění výzkumů se sluchově postiženými je náročné. Tyto skupiny lidí jen obtížně do svého kolektivu přijímají a akceptují tzv. normální - slyšící jedince. Lidé se sluchovým postižením, jsou plaší, nejistí, mívají nižší sebevědomí a velmi subjektivní sebehodnocení. Zvláště, jsou- li v kontaktu, byt' dlouhodobějším, s někým, kdo nepatří do ,jejich“ komunity bývají často ostýchaví, stydí se za svůj handicap a bývají značně uzavření a nedůvěřiví. Proniknout přes tato úskalí je náročné a vyžaduje dlouhodobé úsilí s nejistým výsledkem.

V rámci vstupních a výstupních měření bylo velice důležité zajistit a dodržet stejné podmínky pro všechny testované osoby (čas, teplota, vlhkost, atmosféra, nálada, stejný postup zadání a vysvětlení před testováním atd.) resp., snaha eliminovat všechny negativní proměnné (aby nedošlo k nežádoucímu ovlivnění výsledků měření, a následně tak $\mathrm{k}$ jejich celkovému znehodnocení).

U mužů byly výsledky v testu úrovně aspirace v průměru o hodnotu 1,81 bodu lepší na konci experimentu než na začátku experimentu, přičemž největší zlepšení bylo o 3,66 a nejmenší 0 . U žen byly výsledky v testu úrovně aspirace v průměru o hodnotu 0,25 lepší na konci experimentu než na začátku experimentu, přičemž největší zlepšení bylo o 5,99 a nejmenší o 1,00. Největší zhoršení bylo o - 5,66 a nejmenší o - 0,8 bodu.

Celkově byly výsledky vlivem intervenčního pohybového programu $\mathrm{v}$ testu úrovně aspirace, měřené standardizovaným Testem aspirace (Bakalář, 1987) na konci experimentu lepší o hodnotu 0,92 než před jeho zahájením. Ke zlepšení došlo u 9 probandů ( $\mathrm{z}$ toho 4 chlapci a 5 dívek), nezměněný stav zůstal u 2 probandů ( 2 chlapci) u 3 došlo k určitému poklesu aspirační úrovně tj. u 3 dívek (tab. 2, obr. 2).

Dle tab. 1 - 2 a obr. 1 - 2 lze konstatovat, že na základě výsledků měření a porovnání změny rozložení četnosti $\mathrm{v}$ daných pásmech normy testu pozornosti bylo zjištěno, že nejvíce jedinců při vstupním měření se nacházelo $\mathrm{v}$ posledním 5 pásmu tj. $\mathrm{v}$ rozmezí hodnot $-1,5$ a níže ( 7 jedinců). Při výstupním měření skončilo nejvíce jedinců ve 3 a 4 pásmu tj. v rozmezí $-1,5$ až +1 (4 jedinci) resp. v rozmezí $-1,5$ a níže (také 4 jedinci). Další změna je rovněž patrná i ve 2 a 3 pásmu tj. v rozmezí 3,00 - 4,99 (3 jedinci) resp. v rozmezí 1,00 - 2,99 (3 jedinci), což je zlepšení. V posledním pásmu normy tj. v rozmezí hodnot $-1,5$ a níže se zmenšil počet z původních 7 na pouze 4 probandy.

Na začátku experimentu bylo v předposlední čtvrté a poslední páté kategorii tzv. nízká a velmi nízká úroveň aspirace 12 žáků z celkových 14. Na konci experimentu se zmenšil tento počet již na 8 žáků.

Ve druhé a ve třetí kategorii tzn. normální a vysoká úroveň aspirace byli začátku experimentu pouze 2 žáci. $\mathrm{Na}$ konci tohoto experimentu se ovšem zvýšil počet žáků z výše uvedených 2 na 6 žáků.

Celkově tedy lze konstatovat, že výše uvedený experimentální činitel a jeho obsah měli signifikantní vliv na rozvoj aspirace u mládeže dané kategorie, přestože toto tvrzení je platné pouze pro tuto skupinu.

Stanovená hypotéza, že vlivem intervenčního programu se zvýší úroveň aspirace u experimentální skupiny mládeže se sluchovým postižením, byla potvrzena. 


\section{ZÁVĚR}

Stanovená hypotéza, že vlivem intervenčního programu se zvýší úroveň aspirace u experimentální skupiny mládeže se sluchovým postižením, byla potvrzena. Výzkum potvrdil předpoklad, že sebeobrana, resp. její základy společně s psychomotorikou mají zřetelný vliv na rozvoj aspirace u vybrané skupiny adolescentů se sluchovým postižením.

Je možné konstatovat, že obsah experimentálního činitele, tj. sebeobrana společně s psychomotorikou, dobře ovlivňují výše uvedené parametry u mládeže se sluchovým postižením a proto je vhodné tyto aktivity zařazovat do výuky tělesné výchovy i do mimoškolních pohybových aktivit.

\section{Literatura}

ABRAMENKOVÁ, V, V., et al. Stručný psychologický slovník. 1. vyd. Bratislava: Pravda, 1987. BAKALÁŘ, E., KOPSKÝ, V. I dospěli si mohou hrát. 2. vyd. Praha: Pressfoto, 1987.

BLAHUTKOVÁ, M. Pohyb a duševní zdraví. Brno: Paido, 2005.

BLAHUTKOVÁ, M. Psychomotorické hry pro děti s poruchami pozornosti a pro hyperaktivni dèti. Brno: Paido, 2005.

DLOUHÝ, M. Morálně volní vlastnosti a jejich vliv na dotváření osobnosti středoškolské mládeže. Rigorózní práce, Masarykova univerzita, Fakulta sportovních studií. Brno, 2002.

HRABAL, V. Pedagogicko psychologická diagnostika žáka. 1. vyd. Praha: SPN, 1989.

KURFÜRST, Z. Wu shu, Kung Fu. Adamov: Temple, 1994.

NAKAYAMA, M. Karate. Praha: Naše vojsko, 1994.

NAKONEČNÝ, M. Lexikon psychologie. 1.vyd. Praha: Vodnáŕ, 1995.

OYAMA, M. This is karate. Tokyo: Japan publication, 1966.

PIPEKOVÁ et al. Kapitoly ze speciální pedagogiky. Brno: Paido, 2006. 